\title{
Relationship Of Sleep Quality With The Event Of Hypertension In Elderly In Tresna Werdha Social Protection In West Java Province
}

\section{Hubungan Kualitas Tidur Dengan Kejadian Hipertensi Pada Lansia Di Panti Perlindungan Sosial Tresna Werdha Provinsi Jawa Barat}

Devi Ratnasari, Eti Suliyawati, Aji Lasmana, Andri Nugraha

\begin{abstract}
Sleep is a basic human need that must be fulfilled. As you get older the quality of one's sleep will decrease. Sleep quality is a measure where a person can easily start sleeping, can maintain a state of sleep and get adequate REM and NREM sleep stages. Poor sleep quality can increase the risk of hypertension, heart disease, and other medical conditions. Hypertension is the main risk factor for cardiovascular disease and is known as the silent killer because it is asymptomatic. The purpose of this study was to determine the relationship between sleep quality and the incidence of hypertension in the elderly.

The type of research used was correlative with a case control approach, the sampling technique was purposive sampling with 74 elderly people divided into control groups and case groups. Data collection uses PSQI (Pittsburgh Sleep Quality Index) and medical records, then analyzed by Chi-square.

The results showed that there was a correlation between sleep quality and the incidence of hypertension in the elderly at the Tresna Werdha Social Institution in West Java Province $(p=0.047, p$ $<0.05$ ) with a low closeness rate of 0.225 . Health workers are expected to be able to provide information about the factors that influence the incidence of hypertension and make efforts that can improve sleep quality in the elderly.
\end{abstract}

Keywords: Hypertension, Sleep Quality, Elderly

Afiliasi Penulis

STIKes Karsa Husada Garut

Korespondensi kepada

D. Ratnasari

dv_pratama13@yahoo.com 


\section{Intisari}

Tidur merupakan kebutuhan dasar manusia yang harus dipenuhi. Seiring bertambahnya usia kualitas tidur seseorang akan menurun. Kualitas tidur merupakan ukuran dimana seseorang itu dapat dengan mudah memulai tidur, dapat mempertahankan keadaan tidur dan mendapatkan tahapan tidur REM dan NREM yang cukup. Kualitas tidur yang buruk dapat meningkatkan resiko hipertensi, penyakit jantung, dan kondisi medis lainnya. Hipertensi merupakan faktor resiko utama penyebab penyakit kardiovaskuler dan dikenal sebagai silent killer (pembunuh dalam diam) karena tanpa gejala. Tujuan penelitian ini untuk mengetahui hubungan antara kualitas tidur dengan kejadian hipertensi pada lansia.

Jenis penelitian yang digunakan adalah korelatif dengan pendekatan case control, teknik pengambilan sampel dengan purposive sampling sebanyak 74 lansia yang dibagi menja kelompok kontrol dan kelomok kasus. Pengumpulan data menggunakan PSQI (Pittsburgh Sleep Quality Index) dan rekam medis, kemudian dianalisis dengan Chi-square.

Hasil penelitian menunjukan ada hubungan antara kualitas tidur dengan kejadian hipertensi pada lansia di Panti Sosial Tresna Werdha Provinsi Jawa Barat $(p=0,047, p<0,05)$ dengan tingkat keeratan yang rendah yaitu 0,225 . Petugas kesehatan diharapkan dapat memberikan informasi tentang faktor-faktor yang mempengaruhi kejadian hipertensi dan melakukan upaya-upaya yang dapat meningkatkan kualitas tidur pada lansia.

Kata Kunci: Hipertensi, Kualitas Tidur, Lansia

\section{Pendahuluan}

Hipertensi merupakan salah satu penyakit tidak menular yang sampai saat ini masih menjadi masalah kesehatan secara global, baik di negara maju maupun di negara berkembang. Hipertensi merupakan suatu keadaan tekanan darah mengalami kenaikan karena gangguan pada pembuluh darah, sehingga suplai oksigen dan nutrisi ke jaringan tubuh yang membutuhkannya menjadi terganggu (Nurarif \& Kusuma, 2015). Apabila hipertensi tidak ditangani dengan baik, maka dapat menimbulkan penyakit stroke, penyakit jantung koroner, gagal jantung, demensia, gagal ginjal, dan gangguan penglihatan. Beberapa faktor yang dapat mempengaruhi tekanan darah yaitu faktor umur, jenis kelamin, genetik, nutrisi, obesitas, olah raga, stress, merokok, dan kualitas tidur seseorang yang buruk (Susilo \& Wulandari, 2011).

Lanjut usia atau lansia merupakan tahap akhir dari kehidupan manusia dan merupakan proses alami yang akan dijalani dan tidak dapat dihindari oleh setiap manusia sebagai makhluk hidup. Setiap lansia akan mengalami sebuah proses yaitu proses menua (aging) yang merupakan suatu proses perubahan seorang dewasa sehat menjadi seorang yang lemah (frail) dengan terjadinya perubahan fungsi fisiologis dan psikologis pada lansia (Sudoyo, 2010). Proses degenerasi pada lansia menyebabkan tidur efektif semakin berkurang, sehingga tidak mencapai kualitas tidur yang baik. Perubahan irama sirkardian pada lansia ditunjukkan dengan terjadinya perubahan tidur lansia pada fase NREM (Non Rapid Eye Movement) 3 dan 4, sehingga lansia hampir tidak memiliki fase 4 atau tidur dalam.

\section{Metode}

Jenis penelitian ini menggunakan jenis rancangan penelitian korelatif dengan pendekatan case control. Adapun variable yang diteliti adalah kualitas tidur dan kejadian hipertensi pada lansia. Teknik sampling yang digunakan adalah purposive sampling dengan jumlah sample 74 lansia yang terbagi menjadi dua kelompok yaitu kelompok kasus yaitu lansia dengan hipertensi dan kelompok control yaitu lansia tanpa hipertensi. Pengumpulan data untuk variable kulaitas tidur menggunakan PSQI (Pittsburgh Sleep Quality Index), sedangkan 
Tabel 1 | Distribusi frekuensi responden berdasarkan umur

$\begin{array}{lcccccc}\text { Karakteristik Responden } & \text { Jumlah } & \text { Persentase } & \text { Min } & \text { Max } & \text { Mean } & \text { SD }\end{array}$ Kelompok kasus

(n) (\%)

\begin{tabular}{|c|c|c|c|c|c|c|c|}
\hline & Lansia (elderly) & 17 & 45,9 & \multirow{2}{*}{62} & \multirow{2}{*}{86} & \multirow{2}{*}{74,86} & \multirow{2}{*}{7,227} \\
\hline & Lansia tua (old) & 20 & 54 & & & & \\
\hline \multicolumn{8}{|l|}{ Kelompok kontrol } \\
\hline & Lansia (elderly) & 26 & 70,3 & \multirow{2}{*}{60} & \multirow{2}{*}{83} & \multirow{2}{*}{70,43} & \multirow{2}{*}{6,261} \\
\hline & Lansia tua (old) & 11 & 29,7 & & & & \\
\hline
\end{tabular}

untuk variabel kejadian hipertensi menggunakan rekam medis, kemudian data tersebut dianalisis menggunakan Chi-square.

\section{Hasil \& Pembahasan}

Responden pada penelitian ini seluruhnya berjenis kelamin perempuan yang di bagi rata menjadi dua kelompok yaitu kelompok kasus (hipertensi) dan kelompok kontrol (non hipertensi). yang dilihat berdasarkan hasil rekam medik lansia. Menurut Edward O Bixler, et al. (2009) bahwa wanita post menopausal memiliki kualitas tidur yang menurun yang diakibatkan perubahan hormonal pada wanita post menopausal. Wanita memiliki kualitas tidur yang buruk disebabkan karena terjadi penurunan pada hormon progesteron dan estrogen yang mempunyai reseptor di hipotalamus, sehingga memiliki andil pada irama sirkardian dan pola tidur secara langsung.

Berdasarkan usia responden, dari hasil penelitian didapatkan bahwa rata-rata usia pada kelompok kasus yaitu 74,86 tahun, berdasarkan klasifikasi usia sebagian dari responden $(54,1 \%)$ merupakan kategori lansia tua atau old dan sebagian lagi $(45,9 \%)$ termasuk kategori lansia atau elderly. Sedangkan pada kelompok kontrol rata -
Distribusi frekuensi responden berdasarkan kualitas tidur
Karakteristik Responden

Hipertensi

$\begin{array}{ccc}\text { Kualitas tidur buruk } & 17 & 45,9 \\ \text { Kualitas tidur baik } & 20 & 54\end{array}$

umlah Persentase

(n) (\%)

\begin{tabular}{ccc}
\hline Kualitas tidur buruk & 26 & 70,3 \\
\hline Kualitas tidur baik & 11 & 29,7
\end{tabular}

rata usia responden 70,43 tahun, dimana sebagian besar responden (70,3\%) merupakan kategori lansia atau elderly dan hanya sebagian kecil responden $(29,7 \%)$ termasuk dalam kategori lansia tua atau old. Dari hasil penelitian ini juga diketahui bahwa kualitas tidur lansia pada kelompok kasus sebagian besar $(78,4 \%)$ mengalami kualitas tidur yang buruk, untuk kelompok kontrol sebagian dari responden $(56,8 \%)$ mengalami kualitas tidur buruk. Usia menjadi salah satu faktor yang mempengaruhi tidur dan kebutuhan tidur seseorang. Kebutuhan tidur berkurang seiring dengan bertambahnya usia. Hal ini sesuai dengan penelitian Khasanah dan Hidayat (2012) bahwa lansia yang rentan memiliki kualitas tidur buruk berada pada rentan usia 60-74 tahun.

Dari hasil analisis data didapatkan nilai $p<0,05$ yaitu 0,047 , yang berarti terdapat hubungan antara kualitas tidur dengan kejadian hipertensi pada

Tabel 3 | Hubungan Status Gizi dengan Kejadian ISPA pada balita di Puskesmas Mekarwangi Garut

\begin{tabular}{lccccccc}
\multirow{2}{*}{ Karakteristik } & \multicolumn{4}{c}{ Kejadian } & P Value & C & $\begin{array}{l}\text { Odds } \\
\text { Ratio }\end{array}$ \\
\cline { 2 - 6 } & hipertensi & $\%$ & Non hipertensi & $\%$ & & & \\
Kualitas tidur buruk & 30 & 52,6 & 6 & 10,5 & 0,047 & 0,225 & 2,762
\end{tabular}


lansia di Di Panti Perlindungan Sosial Tresna Werdha Provinsi Jawa Barat. Hasil penelitian ini didukung oleh pendapat Calhoun dan Harding (2010), apabila seseorang mangalami kebiasaan durasi tidur yang pendek atau kualitas tidur yang buruk maka dapat meningkatkan tekanan darah. Kualitas tidur yang buruk dapat mengakibatkan hormon pengaturan keseimbangan tekanan darah atau hormon aldosteron tidak bekerja secara optimal, sehingga kehilangan waktu tidur dapat membuat sistem saraf menjadi hiperaktif yang kemudian mempengaruhi sistem seluruh tubuh termasuk jantung dan pembuluh darah. Penelitian tersebut juga diperkuat oleh Wang et al (2012) yang menyatakan bahwa durasi tidur yang pendek terkait dengan perubahan emosi seperti mudah marah, pesimis, tidak sabar, lelah dan stress yang akan membuat seseorang lebih sulit mempertahankan gaya hidup sehat, sehingga meningkatkan resiko hipertensi.

Hubungan antara kedua variabel memiliki tingkat keeratan yang rendah dengan nilai 0,225 (01). Hal ini dapat disebabkan adanya pengaruh dari faktor-faktor lain yang mempengaruhi kedua variabel. Menurut Kozier dan Shirlee (2010) faktor - faktor yang mempengaruhi tidur seseorang antara lain penyakit fisik lain (reumatik, rhematoid arthritis, gout, gastritis, dermatitis, dan lain-lain), obat-obatan yang dikonsumsi, gaya hidup, stress emosional, lingkungan, latihan fisik, asupan makanan dan gangguan tidur. Sedangkan faktorfaktor yang mempengaruhi tekanan darah meliputi genetik, umur, jenis kelamin, stress, kegemukan, nutrisi, kurang olahraga dan kolestrol tinggi (Triyanto, 2014). Lansia di Panti Perlindungan Sosial Tresna Werdha Provinsi Jawa Barat memiliki kualitas tidur yang kurang baik, lansia mengeluhkan terkait tidurnya yang sering terganggu karena efek dari penyakit yang dialaminya. Banyak lansia yang belum bisa beradaptasi dengan perubahan fisiologis khususnya perubahan pola tidur yang dapat menyebabkan stress emosional pada lansia.

\section{Kesimpulan}

Penelitian ini menunjukan sebagian besar lansia pada kelompok kasus memiliki kualitas tidur yang buruk, sehingga dari hasil analisis data penelitian ini dapat disimpulkan bahwa terdapat hubungan antara kualitas tidur dengan kejadian hipertensi pada lansia di Panti Perlindungan Sosial Tresna Werdha Provinsi Jawa Barat.

\section{Bibliografi}

1. Nurarif, A.H., dan Kusuma H. 2015. Aplikasi Asuhan Keperawatan Berdasarkan Diagnosa Medis \& NANDA NIC-NOC. MediAction. Yogyakarta.

2. Susilo dan Wulandari. 2011. Cara Jitu Mengatasi Hipertensi.. CV Andi. Yogyakarta.

3. Suhardjono. 2010. Hipertensi Pada Lansia. Dalam : Sudoyo A.W., Bambang S., Idrus A (editor). Buku Ajar Ilmu Penyakit Dalam Jilid I Edisi V. Interna Publishing. Jakarta.

4. Edward O Bixler, et al. 2009. Women Sleep Objectively Better Than Men and The Sleep of Young Women is More Resilient to External Stressor : Effects of Age and Menopause. National Health Institution Access Journal Sleep. 18:221-228.

5. Khasanah, K. \& Hidayati. 2012. Kualitas Tidur Lansia Balai Rehabilitas Sosial Mandiri Semarang. Journal Nursing Studies. $1: 189-196$.

6. Calhoum D.A and Harding S.M. 2010. Sleep and Hypertension. Chest Journal. 138(2): 434-443

7. Wang, Qijuan et al. 2012. Short Sleep Duration is Associated with Hypertension Risk Among Adults: A Systematic Review and Meta-analysis. Hypertension Research Journal. 35:1012-1018.

8. Kozier, B., Berman, A and Shirlee J. snyde. 2010. Buku Ajar Fundamental Keperawatan Konsep Proses dan Praktik edisi VII. Volume I. diterjemahkan oleh Eko Karyuni, dkk. EGC. Jakarta.

9. Triyanto, Endang. 2014. Pelayanan Keperawatan Bagi Penderita Hipertensi Secara Terpadu. Graha Ilmu. Yogyakarta. 